\title{
Revealing Potency of Bioactive Compounds as Inhibitor of Dengue Virus (DENV) NS2B/NS3 Protease from Sweet Potato (Ipomoea batatas L.) Leaves
}

\author{
Viol Dhea Kharisma ${ }^{1,2}$, Rasyadan Taufiq Probojati ${ }^{1}$, Ahmad Affan Ali Murtadlo ${ }^{1}$, Arif Nur Muhammad \\ Ansori $^{3}$, Yulanda Antonius ${ }^{4}$, Muhammad Badrut Tamam ${ }^{1,5}$ \\ ${ }^{1}$ Researcher, Division of Molecular Biology and Genetics, Generasi Biologi Indonesia Foundation, Gresik, \\ Indonesia, ${ }^{2}$ Master Student, Master Program in Biology, Department of Biology, Faculty of Mathematics and \\ Natural Sciences, Brawijaya University, Malang, Indonesia, ${ }^{3}$ Doctoral Student, Doctoral Program in Veterinary \\ Science, Faculty of Veterinary Medicine, Universitas Airlangga, Surabaya, Indonesia, ${ }^{4}$ Lecturer, Department of \\ Biology, Faculty of Biotechnology, University of Surabaya, Surabaya, Indonesia, ${ }^{5}$ Lecturer, Department of Biology, \\ Faculty of Sciences and Technology, Universitas Muhammadiyah Lamongan, Lamongan, Indonesia
}

\begin{abstract}
This study aims to identify the potency of bioactive compounds of sweet potato leaf as inhibitory agent to dengue virus (DENV) NS2B/NS3 protease by using computational study. The 3D structure of NS2B/ NS3 protease was collected from PDB and the 2D structure of several bioactive compounds of sweet potato leaf were obtained from PubChem. The visualization and data analysis were performed by using the PyMol software. According to the in silico analysis, result demonstrated that dehydroabietinol had the lowest free energy binding. However, based on the protein-ligand analysis, all the compounds showed the hydrogen bond and hydrophobic interaction. All the compounds with hydrogen bond could not be interacted with catalytic domain, but hydrophobic interaction could be interacted to the target domain via Ser135 by $\delta$-Selinene and His51 by $\alpha$-Caryophyllene. In summary, we conclude that $\delta$-Selinene and $\alpha$-Caryophyllene might have potencies as a therapeutically drug for dengue.
\end{abstract}

Keywords: Dengue virus, in silico, Ipomoea batatas, protease

\section{Introduction}

Indonesia is a tropical country and home of mosquito vector species of dengue virus (DENV), Aedes aegypti and Aedes albopictus ${ }^{[1]}$. DENV is infectious agent dengue fever-causing epidemic diseases, current antiviral drug cannot succeed against this entity. Therefore, the development of the drug is required to treat DENV infection ${ }^{[2]}$. DENV is member family from Flaviviridae and consist of four serotypes (DENV 1-4) [3].

\footnotetext{
Corresponding Authors:

Yulanda Antonius

yulandaantonius@staff.ubaya.ac.id

Muhammad Badrut Tamam

mh.badruttamam@gmail.com
}

Indonesia is a large country in Southeast Asia and has a high plant diversity in the world. There are more than 5,000 medicinal plants that available all around us ${ }^{[4]}$. Consequently, medicinal plants used by its population in curing many diseases ${ }^{[5,6]}$. The medicinal plants generate a variant of chemical composition with the potency to prevent viral replication and probable resource for controlling viral infection ${ }^{[7]}$. Plants have been described to have antiviral action and some have been accustomed to manage viral taints in humans and animals $^{[8]}$. Medicinal plants were found for antiviral compounds, such as Convolvulaceae ${ }^{[9]}$.

DENV is a single stranded and positive polarity RNA virus with a genome of about 11,000 bases in length. The genome encodes for three structural proteins and nonstructural proteins, its activated by trypsin-like NS2B/ NS3 protease. This enzyme has a catalytic triad domain, 
it contains a specific amino acid residual His51, Asp75, and Ser135 required for catalytic activity ${ }^{[10]}$. Protease complex NS2B/NS3 have a key role in viral replication and make it's as a therapeutic target to development of protease inhibitor for DENV infection ${ }^{[11]}$. In addition, sweet potato bioactive compounds reported as a potent inhibitor of the virus ${ }^{[12]}$. Previous research by Pochapski et al. (2011) explained that chemical compound contained in sweet potato have potency as a drug but this mechanism action is unknown ${ }^{[13]}$. Therefore, we identified the potency of bioactive compounds of sweet potato leaf as inhibitory agent to DENV NS2B/NS3 protease by using computational study.

\section{Materials and Methods}

\section{Collection of NS2B/NS3 serine protease}

The target protein in this research is DENV NS2B/ NS3 protease. Therefore, the 3D structure of NS2B/NS3 serine protease was obtained from protein database or RCSB with ID 2FOM. Furthermore, the protein was validated the model quality by using Ramachandran plot.

\section{Collection of sweet potato leaves compounds}

Various bioactive compounds from sweet potato leaves referred to previous research ${ }^{[14]}$ were retrieved from PubChem. The 3D structure of compound has collected in structure data format (SDF). Therefore, it must be converted by Open Babel software to produce flexibility 3D structure with protein data bank (PDB) format.

\section{Molecular docking of NS2B/NS3 serine protease with sweet potato leaves compounds}

Screening the potency of sweet potato leaves compounds by using virtual screening was conducted with molecular docking. There are several methods which could be applied by using molecular docking, such as specific docking and blind docking ${ }^{[15,16,17]}$. This research was conducted by using blind docking by PyRx software to identify the potency of bioactive compound from sweet potato leaves as inhibitor NS2B/NS3.

Visualization of interaction between NS2B/NS3 serine protease with sweet potato leaves compounds

Then, we were using PyMol to visualize 3D liganprotein structure of NS2B/NS3 serine protease and various compounds of sweet potato. Furthermore, those interaction were analyzed by using LigPlot to compared chemical interaction ${ }^{[18,19]}$.

\section{Results and Discussion}

DENV is a single stranded and positive polarity RNA virus with a genome of about 11,000 bases in length. The genome encodes for three structural proteins and nonstructural proteins, its activated by trypsin-like NS2B/NS3 protease. This enzyme has a catalytic triad domain, it contains a specific amino acid residual His51, Asp75, and Ser135 required for catalytic activity ${ }^{[10,11]}$. Protease complex NS2B/NS3 have a key role in viral replication and make it's as a therapeutic target to development of protease inhibitor for DENV infection.

The 3D structure has been obtained from PubChem, around thirty-six of a bioactive compound that's contained in the leaf essential oil of sweet potato, then its minimize by Open Babel because then its minimize by Open Babel because it's will making this ligand have lowest binding energy and generate structure flexibility NS2B/NS3 serine protease (2FOM) obtain from PDB, and then validating structure has been done using RAMPAGE, the result of structure validation showed by Ramachandran plot. Structure validation aims to evaluate the structure quality of targeted protein which is quantify by the number of favored amino acid that reach more than $90 \%{ }^{[19]}$. In this study, targeted protein was visualized based on surfaces structure. Furthermore, the NS2B/NS3 structure is arranged from two chain, A and $\mathrm{B}$ which contain $\alpha$-helix, $\beta$-sheet, and coil. 


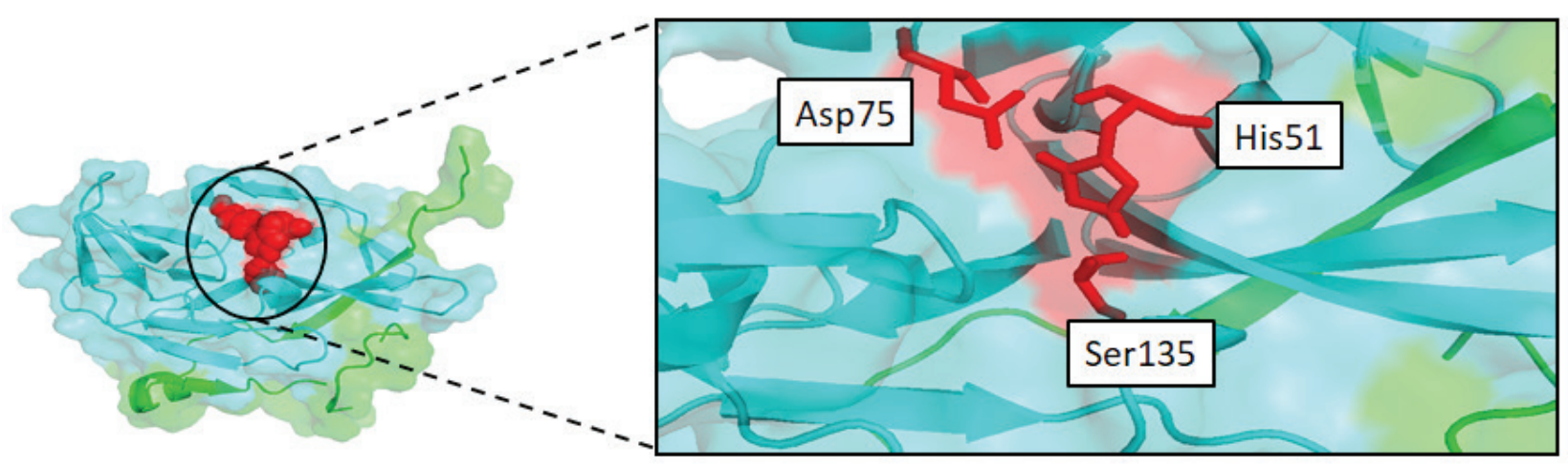

Figure 1. Catalytic triad visualization on NS3/NS2B DENV. Targeted protein was shown in transparent surfaces structure (cyan) and cartoons (green), while the catalytic triad as drug target shown in stick structure colored in red to distinguish the drug target domain with the others.

Molecular docking is a part of in silico analysis that has main objective to identify the energy binding size and the interaction pattern between protein and its ligand according to the chemical interaction within the complex ${ }^{[16]}$. Molecular docking has performed by PyRx software to know binding affinity level with grid positions $\mathrm{x}:-0,4637 \mathrm{y}:-15,1662 \mathrm{z}: 16,1087$ and dimensions $(\AA)$ x: 52,1952 y: $56,6277 \mathrm{z}: 46,8960$ reffer to catalytic site domain on NS2B/NS3 serine protease with amino acid residual is His51, Asp75, and Ser135, that be visualized by PyMol software as stick in cartoon structure with surface on target protein (Figure 1). After we know the positions of the catalytic site, then docking grid was directed to its. Docking result indicated that compound has a lowest binding affinity is dehydroabietinol around $-7,1 \mathrm{kcal} / \mathrm{mol}$. We revealed another results, such as abietadiene $(-6.9 \mathrm{kcal} / \mathrm{mol})$, cembrene $(-6.6 \mathrm{kcal} / \mathrm{mol})$, $\delta$-selinene $(-6.5 \mathrm{kcal} / \mathrm{mol}), \delta$-cadinene $(-6.4 \mathrm{kcal} / \mathrm{mol})$, spathulenol (-6.2 kcal/mol), $\beta$-cuvebene $(-6.0 \mathrm{kcal} /$ mol), $\gamma$-gurjunene $(-5.9 \mathrm{kcal} / \mathrm{mol}), \alpha$-bergamotenol (-5.8 kcal $/ \mathrm{mol}), \quad \beta$-caryophyllene $(-5.8 \mathrm{kcal} / \mathrm{mol})$, $\beta$-elemene $(-5.8 \mathrm{kcal} / \mathrm{mol})$, allo-aromadendrene $(-5.7$ $\mathrm{kcal} / \mathrm{mol}), \beta$-chamigrene $(-5.7 \mathrm{kcal} / \mathrm{mol}), \beta$-panasinsene $(-5.7 \mathrm{kcal} / \mathrm{mol})$, trans- $\alpha$-bergamotene $(-5.7 \mathrm{kcal} / \mathrm{mol})$, caryophyllene oxide $(-5.6 \mathrm{kcal} / \mathrm{mol}), \gamma$-elemene $(-5.6$ $\mathrm{kcal} / \mathrm{mol})$, longifolene $(-5.6 \mathrm{kcal} / \mathrm{mol}), \alpha$-caryophyllene (-5.5 kcal $/ \mathrm{mol}), \alpha$-thujene $(-5.5 \mathrm{kcal} / \mathrm{mol})$, octadecanoic acid $(-5.5 \mathrm{kcal} / \mathrm{mol})$, bicyclogermacrene $(-5.4 \mathrm{kcal} / \mathrm{mol})$, limonene $(-5.3 \mathrm{kcal} / \mathrm{mol})$, terpinen-4-ol $(-5.3 \mathrm{kcal} / \mathrm{mol})$, eugenol $(-5.2 \mathrm{kcal} / \mathrm{mol}), \mathrm{n}$-hexadecanoic acid $(-5.2 \mathrm{kcal} /$ $\mathrm{mol}), \alpha$-farnesene $(-5.1 \mathrm{kcal} / \mathrm{mol}), \alpha$-santalol $(-5.1 \mathrm{kcal} /$ $\mathrm{mol}), \gamma$-terpinene $(-5.1 \mathrm{kcal} / \mathrm{mol}), \mathrm{p}$-cymene $(-5.1 \mathrm{kcal} /$ $\mathrm{mol})$, p-menth-1-ene $(-5.1 \mathrm{kcal} / \mathrm{mol})$, bicycloelemene $(-5.0 \mathrm{kcal} / \mathrm{mol}), \alpha$-pinene $(-4.8 \mathrm{kcal} / \mathrm{mol}), \beta$-pinene $(-4.8$ $\mathrm{kcal} / \mathrm{mol})$, cis-sabinene $(-4.8 \mathrm{kcal} / \mathrm{mol})$, and 1 -octen-3Ol $(-4.5 \mathrm{kcal} / \mathrm{mol})$. Binding affinity is energy bonding formed from the interactions some molecule with other, several parameters affect binding affinity such as amino acid residues and type of chemical interaction between ligand-protein such hydrogen, hydrophobic, and Van der Waals. Binding affinity commonly used as indicator of binding energy to determine the complex interaction which is considering as biological activity outcome ${ }^{[16]}$. 


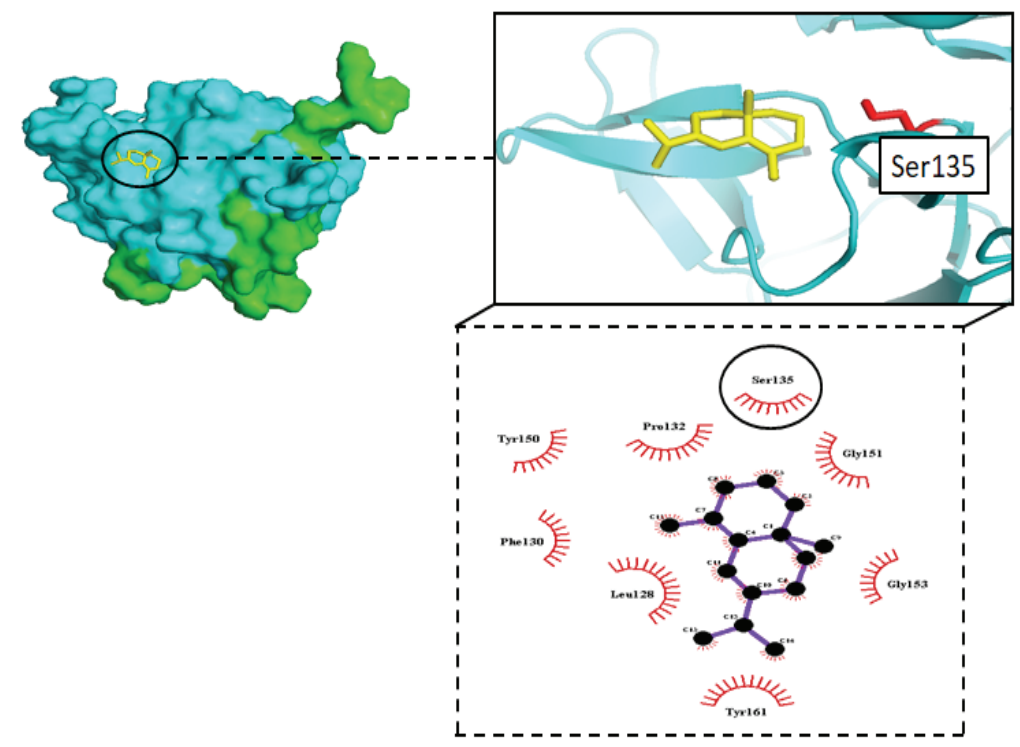

Figure 2. Targeted domain and $\delta$-Selinene interaction. The ligand was shown as yellow stick structure, while the specific residual amino acid was shown as red color. The hydrophobic interaction was occurring in Ser135 area shown in black circle.

Based on results of molecular docking, a bioactive compound from sweet potato leaves have a potency to bind NS2B/NS3 with lowest binding affinity and possible formed stable complex of ligand-protein. The amount of free energy $(\Delta \mathrm{G})$ indicating as an ability of binding for a bioactive compound to the target protein. In this condition, the ligand bind to target protein and making of energy alteration such Gibbs free energy $(\Delta G)$, it has negative value when the system in equilibrium condition with constant pressure and temperature, because the widely of protein-ligand association can be determined by negative $\Delta \mathrm{G}$, so its determination of the proteinligand complex or ligand binding affinity ${ }^{[20]}$.

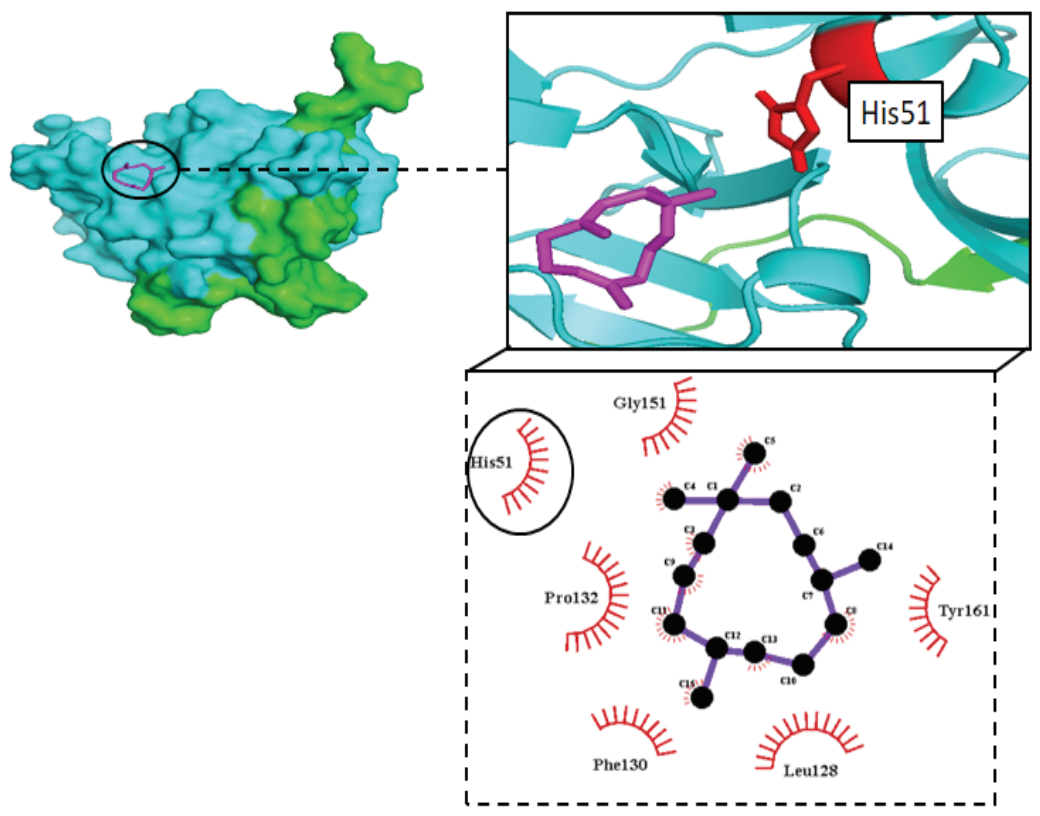

Figure 3. The $\alpha$-Caryophyllene interaction to targeted domain. The ligand was shown as purple stick structure, while the red color is the residual amino acid in NS2B/NS3. The hydrophobic interaction was occurring in Ser135 which shown inside the black circle. 
Potency as inhibitor NS2/NS3 serine protease in the oil essential of sweet potato leaves showing dehydroabietinol have lowest free energy binding, but refer to the result of analysis of protein-ligand domain interaction of the all compound showing, it's had two type of chemical interaction between ligand with protein domain as hydrogen bond and hydrophobic. All of the compounds have hydrogen bond cannot be interacted with catalytic domain, but hydrophobic interaction can be interacted to target domain, via Ser 135 by $\delta$-Selinene (Figure 2) and His51 by $\alpha$-Caryophyllene (Figure 3). Catalytic triad (Ser135, His51, and Asp75) can be found in NS2B/NS3 and required to protease activity which functions as a mechanism for activation of DENV replication ${ }^{[11]}$. So, it is predicted that the two compounds are very possible to interact with the catalytic site domain in NS2B/NS3. Therefore, it can be potentially as an inhibitor compare to dehydroabietinol which has lower binding affinity without chemical interaction site in targeted domain in NS2/NS3 serine protease.

\section{Conclusion}

In summary, the $\delta$-Selinene and $\alpha$-Caryophyllene are predicted to have potency as dengue disease medication through the inhibitory mechanism against DENV. Specifically, the ligands are binding to one of catalytic triad of residual amino acid. This interaction inhibits the targeted protein activation when the virus replication occurs.

Conflict of Interest: The author declare that they have no conflict of interest.

Funding: This study supported by the Generasi Biologi Indonesia Foundation, Indonesia.

Acknowledgements : We would like to declare our sympathy to the victims of COVID-19. Tribute goes to the frontliners worldwide, especially in Indonesia. We thank EJA, Indonesia for editing the manuscript.

Ethical Approval: No ethical approval needed.

\section{References}

1. Ansori ANM, Kusala MJK, Irawan H, et al. Citrus reticulata extract as biocides to control Aedes aegypti, the vector of dengue. Biosci Res. 15(3): 1661-1665.
2. Maria GG, Gubler DJ, Izquierdo A, et al. Dengue infection. J Nat Rev. 2016; 2: 1-21.

3. Guzman MG, Harris E. Dengue. Lancet. 2015; 385: 453-465.

4. Ansori ANM, Susilo RJK, Hayaza S, et al. Renoprotection by Garcinia mangostana L. pericarp extract in streptozotocin-induced diabetic mice. Iraqi J Vet Sci. 2019; 33(1): 13-19.

5. Ansori ANM, Fadholly A, Hayaza S, et al. A review on medicinal properties of mangosteen (Garcinia mangostana L.). Res J Pharm Tech. 2020; 13(2): 974-982.

6. Fadholly A, Ansori ANM, Proboningrat A, et al. Apoptosis of HeLa cells via caspase-3 expression induced by chitosan-based nanoparticles of Annona squamosa leaf extract: In vitro study. Indian J Pharm Res. 2020; 54(2): 416-421.

7. Klawikkan N, Nukoolkarn V, Jirakanjanakir N, et al. Effect of Thai medicinal plant extracts against dengue virus in vitro. Mahidol Univ J Pharm Sci. 2011; 38: 13-18.

8. Ansori ANM, Fadholly A, Proboningrat A, et al. Efficacy of Allium cepa (Amaryllidaceae) extract against dengue virus type-2 (Flaviviridae: Flavivirus) isolated from Surabaya, Indonesia. Biochem Cell Arch. 2020; 20(2).

9. Abd Kadir SL, Yaakob H, Mohamed ZR. Potential anti-dengue medicinal plants: A review. J Nat Med. 2013; 67(4): 677-689.

10. Rushika P, Richard JK. Structural proteomics of dengue virus. Curr Opin Microbiol. 2008; 11(4): 369-377.

11. Wu H, Bock S, Snitko M, et al. Novel dengue virus NS2B/NS3 protease inhibitors. J Antimicrob Agents Chemother. 2015; 59: 1100-1109.

12. Poochi SP, Easwaran M, Balasubramanian B, et al. Employing bioactive compounds derived from Ipomoea obscura (L.) to evaluate potential inhibitor for SARS-CoV-2 main protease and ACE2 protein. Food Front. 2020.

13. Pochapski MT, Fosquiera EC, Esmerino LA, et al. Phytochemical screening, antioxidant, and antimicrobial activities of the crude leaves' extract from Ipomoea batatas (L.) Lam. Pharmacogn Mag. 2011; 7(26): 165-170.

14. Abul ROO, Adebayo MA, Inikpi E, et al. Chemical constituents of essential oil from the leaves of 
Ipomoea batatas L. (Lam.). Int Res J Pure App Chem. 7(1): 42-48.

15. Syafruddin S, Septiadi L, Alfaruqi NTS, et al. In silico analysis and indentification of possible inhibitor of H5N1 virus. J Bioinfo Biomedic Res. 2018; 1(2): 33-39.

16. Kharisma VD, Syfruddin S, Septiadi L. Prediction of novel bioactive compound from $Z$. officinale as non-nucleoside reverse transcriptase inhibitors (NNRTIs) of HIV-1 through computational study. J Bioinfo Biomedic Res. 2018; 1(2): 49-55.

17. Hendra S, Kharisma VD, Listyorini D, et al. Effectivity of black tea polyphenol in adipogenesis related IGF-1 and its receptor pathway through in silico based study. J Physics Conf. 2018; 1093.
18. Seeliger D, de Groot BL. Ligand docking and binding site analysis with PyMOL and Autodock/ Vina. J Comput Aided Mol Des. 2010; 24(5): 417422.

19. Laskowski RA, Swindells MB. LigPlot+: Multiple ligand protein interaction diagrams for drug discovery. J Chem Inf Model. 2011; 51(10): 27782786.

20. Damayanti DS, Utomo DH, Kusuma C. Revealing the potency of Annona muricata leaves extract as FOXO1 inhibitor for diabetes mellitus treatment through computational study. In Silico Pharmacol. 2017; 5(1): 2-7. 
ISSN-0973-9122 (Print) • ISSN-0973-9130 (Electronic)

\begin{tabular}{l|l|l}
\hline Volume 15 & Mumber 1 January-March 2021
\end{tabular}

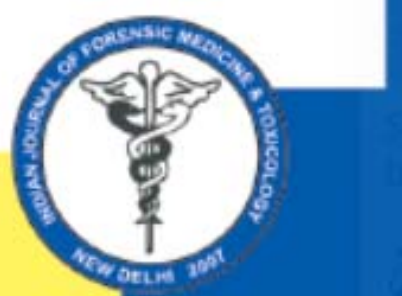

\section{Indian Journal of}

\section{Forensic Medicine \& Toxicology}

Website: www.ijfmt.com

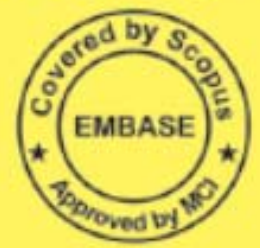

Official Organ of Indian Association of Medico-Legal Experts (Regd.) 


\section{Indian Journal of Forensic Medicine and Toxicology}

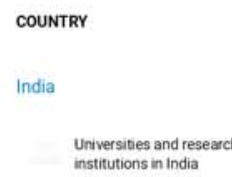

H-INDEX

20

INFORMATION

Homepage

How to publish in this journal

editor.ijfmt@gmail.com

\section{SUBJECT AREA AND CATEGORY}

Environmental Science

Health, Toxicology and Mutagenesis

Medicine

Pathology and Forensic Medicine

Pharmacology, Toxicology and Pharmaceutics

Toxicology

Social Sciences

Law

PUBLICATION TYPE

Journals
PUBUSHER

Indian Journal of Forensic Medicine and Toxicology

ISSN

COVERAGE

09739122,09739130

SCOPE

"Indian Journal of Forensic Medicine \& Toxicology " is a double-blind peer reviewed international journal. The frequency is quarterly. It deals with Forensic Medicine, Forensic Science, Toxicology, DNA fingerprinting, sexual medicine, environmental medicine, Forensic Pathology, legal medicine and public health laws. 
FIND SIMILAR JOURNALS ? Medico-Legal Update

$<\quad$ IND
2

International Journal of Medical Toxicology and Legal

IND
Journal of Indian Academy of Forensic Medicine

IND

$34 \%$
Journal of Punjab Academy of Forensic Medicine and

IND
$53 \%$

similarity

\section{$41 \%$}

similarity
Journal of the Nepal Medical Association

NPL

$30 \%$
similarity $\quad \begin{gathered}29 \% \\ \text { similarity }\end{gathered}$

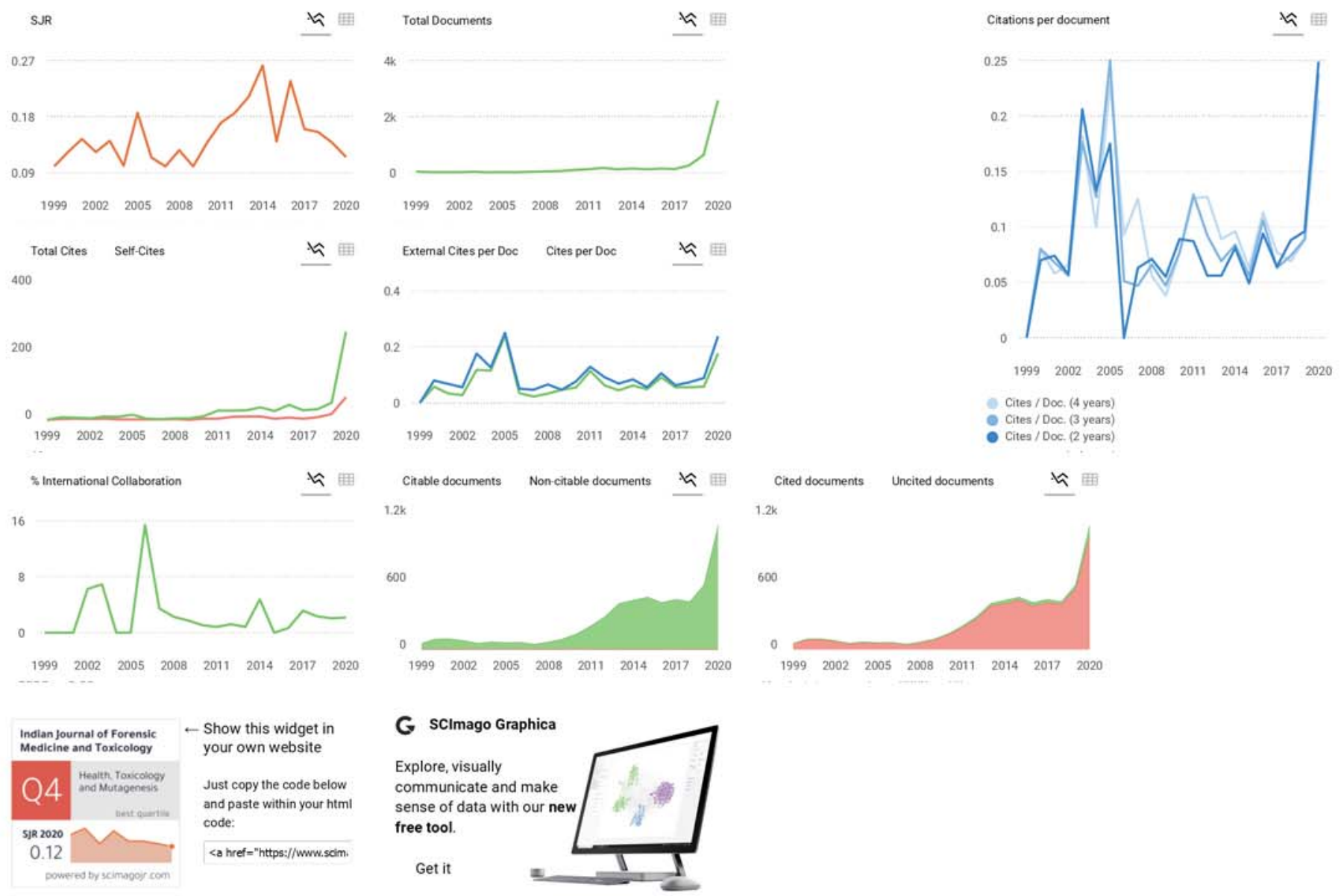




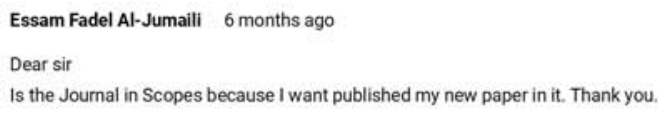

Dear Essam,

Thank you very much for your comment.

All the metadata have been provided by Scopus /Elsevier in their last update sent to SCImago, including the Coverage's period data. The SJR for 2020 has been released on 17 May 2021. We suggest you consult the Scopus database directly to see the current index status as SJR is a static image of Scopus, which is changing every day. Best Regards, SCImago Team

A

anas khaleel 6 months ago

dear

editor says it is no longer in scopus?

is that true?

since May 10, 2021?

best

reply

ahmed ali 4 months ago

Are you asking or giving us information?

\section{Melanie Ortiz 6 months ago}

Dear Anas,

Thank you very much for your comment.

All the metadata have been provided by Scopus / Elsevier in their last update sent to

SCImago, including the Coverage's period data. The SJR for 2020 has been released on 17 May 2021. We suggest you consult the Scopus database directly to see the current index status as SJR is a static image of Scopus, which is changing every day

For further information, please contact Scopus support: https://service.elsevier.com

/app/answers/detail/a_id/14883/kw/scimago/supporthub/scopus/

Best Regards, SCImago Team

hello sir/madam,

indian journal of forensic medicine and toxicology 'Coverage 2008-2019'

is the journal out of Scopus? or someother reason?

thank you and please let me know.

reply

Melanie Ortiz 9 months ago

Dear Aloto,

Thank you very much for your comment.

All the metadata have been provided by Scopus /Elsevier in their last update sent to

SCImago, including the Coverage's period data. The SJR for 2019 was released on 11

June 2020. We suggest you consult the Scopus database directly to see the current index

status as SJR is a static image of Scopus, which is changing every day.

Best Regards, SCImago Team 
how can i see the impact factor of Indian Joumal of Forensic Medicine

reply

Melanie Ortiz 1 year ago

Dear Sekar, thank you very much for your comment. SCImago Journal and Country Rank uses Scopus data, our impact indicator is the SJR (Check it on our website). We suggest you consult the Journal Citation Report for other indicators (like Impact Factor) with Web of Science data source. Best Regards, SCImago Team

\section{Melanie Ortiz 1 year ago}

Dear Muna,

Thank you for contacting us. Our data come from Scopus, they annually send us an update of the data. This update is sent to us around April / May every year. The SJR for 2019 was released on June 2020, 11. Thus, the indicators for 2020 will be available in June 2021 and before that date we can't know what will happen with this journal. Best Regards, SCImago Team

Ali Al-Saffar 1 year ago

Dear Sir/Madam

Are the articles published in this journal covered by SCImago? In SCOPUS web site they already covered.

Regards

Ali

reply

Melanie Ortiz 1 year ago

Dear Ali,

Thank you for contacting us. SCImago doesn't index particular articles but journals. All the Scopus data are sent to SCImago in April/May every year.

Best Regards, SCImago

J J. toma 2 years ago

hello dear

Is the journal out of Scopus because it is written until 2019 in scopus??

thank you

reply

Melanie Ortiz 2 years ago

Dear Sir/Madam

Thank you very much for your comment.

All the metadata have been provided by Scopus /Elsevier in their last update sent to

SCImago, including the Coverage's period data. The SJR for 2019 was updated on June

2020,11 th. We suggest you consult the Scopus database directly to see the current index status as SJR is a static image of Scopus, which is changing every day

Best Regards, SCImago Team 
In scopus coverage of this journal it's showing "Coverage: 2008-2019, what does this mean did the Indian Journal of Forensic Medicine and Toxicology lost scopus or discontinued after 2019? Or someother reason?

Can you please let me know that this having still scopus coverage for 2020 or not?

reply

Melanie Ortiz 2 years ago

Dear Farida,

Thank you very much for your comment.

All the metadata have been provided by Scopus /Elsevier in their last update sent to

SCImago, including the Coverage's period data. The SUR for 2019 was updated on June

2020,11 th. We suggest you consult the Scopus database directly to see the current index status as SJR is a static image of Scopus, which is changing every day.

Best Regards, SCImago Team

Mohammed Eteya 2 years ago

Hello Doctor I want to publish my research in your magazine, how long is the period of acceptance of publication, the period of publication, how many days, and what is the amount of publication in it

reply

Melanie Ortiz 2 years ago

Dear Muhaned,

thank you for contacting us.

We are sorry to tell you that SCImago Journal \& Country Rank is not a journal. SJR is a portal with scientometric indicators of journals indexed in Elsevier/Scopus. Unfortunately, we cannot help you with your request, we suggest you visit the journal's homepage or contact the journals editorial staff , so they could inform you more deeply. Best Regards, SCImago Team

Dear sir/madam

As i am responsible in my university for checking the originality of the journals where our researchers published their researches, after evaluation of this journal, $i$ found it fits with a lot of predatory criteria, riddled with scientific, grammatical and spelling mistakes, and seems that most of the published articles in this journal did not subjected to evaluation or review by reputed reviewers. I couldn't understand why ,Scopus index and SCImago didn't reevaluate this journal and reconsider it again.

Regards

reply

Melanie Ortiz 2 years ago

Dear Salah,

Thank you for contacting us.

SJR is a portal with scientometric indicators of journals indexed in Scopus. All the data

have been provided by Scopus /Elsevier and SCImago doesn't have the authority over this data which are property of Scopus/Elsevier. SCImago has a signed agreement that limits our performance to the generation of scientometric indicators derived from the metadata sent in the last update. We suggest you to contact with Scopus support regarding this matter here:

https://service.elsevier.com/app/answers/detail/a_id/14883/kw/scimago/supporthub /scopus/

Best Regards, SCImago Team

Dear Sir can you please tell me about this journal it has same name with your journal are it possible?

Indian Journal of Forensic Medicine 
Dear Hama,

Could you please expand a little bit your comment? Best Regards, SCImago Team

Aqeel A. Alsadawi 2 years ago

Hello, I am the researcher Aqeel.

A research has been published in your journal entitled

(Treatment and experimental infection with Klebsiella

pneumoniae in Rats)

It has not yet appeared on the Scopus page. Please reply to this message to find out the reason

reply

Melanie Ortiz 2 years ago

Dear Aqueel,

thank you very much for your comment, unfortunately we cannot help you with your

request. We suggest you to contact directly with Scopus support:

https://service.elsevier.com/app/answers/detail/a_id/14883/kw/scimago/supporthub

/scopus/

Best Regards, SCImago Team

Dr. Fouad Fadhil Al-Qaim 2 years ago

Dear Sir/Madam

I have only one question.

How does the same journal gather between science and social science (toxicology and law)?

Please can you explain, why it was considered in SJR data base?

Thank you

reply

Melanie Ortiz 2 years ago

Dear Fouad,

Thank you for contacting us

SUR is a portal with scientometric indicators of journals indexed in Scopus. All the data (Category, Publisher, etc) have been provided By Scopus /Elsevier and SCImago doesn't have the authority over this data which are property of Scopus/Elsevier. SCImago has a signed agreement that limits our performance to the generation of scientometric indicators derived from the metadata sent in the last update.

We suggest you to contact with Scopus support regarding this matter.

https://service.elsevier,com/app/answers/detail/a_id/14883/kw/scimago/supporthub

/scopus/

Best Regards, SCImago Team

sir I want to publish my article and I have prepared accordinly but not able to find the copyright form. please help

reply

Bahram 2 years ago

Hello my dear

Please answer my questions

1 - On what bases does your magazine index? (ISI. Pub med or Scopus)?

2- How many weeks is the maximum arbitration time? Is it possible to make quick judgments?

3. How much does it cost to print an article?

Thank you

reply 
Hello dear: When will the 14th volume of the Indian Journal of Forensic Medicine and Toxicology be published?

Melanie Ortiz 2 years ago

Dear Hanaa,

thank you for contacting us

Unfortunately, we cannot help you with your request, we suggest you to visit the

journal's homepage or contact the journal's editorial staff, so they could inform you

more deeply.

Best Regards, SCImago Team

Melanie Ortiz 2 years ago

Dear Bahram,

thank you for contacting us.

We are sorry to tell you that SCImago Journal \& Country Rank is not a journal. SJR is a

portal with scientometric indicators of journals indexed in Elsevier/Scopus. We sugges you to consult Scopus and/or other databases to know where is this journal indexed in. You can also check that information in the journal's website or contact directly with the editorial staff. For further information about this journal, please visit the journal's website. Best Regards, SCImago Team

is this journal still under scopus.?

reply

Tri Astuti Sugiyatmi 7 months ago

After May 2021, is this journal still indexed by Scopus?

Warm Regard

Melanie Ortiz 7 months ago

Dear Tri Astuti,

Thank you very much for your comment.

All the metadata have been provided by Scopus /Elsevier in their last update sent to SCImago, including the Coverage's period data. The SJR for 2020 has been released on 17 May 2021. We suggest you consult the Scopus database directly to see the current index status as SJR is a static image of Scopus, which is changing every day.

Best Regards, SCImago Team

Raian Zobi 7 months ago

Is journal still under scopous?

Melanie Ortiz 7 months ago

Dear Raian,

Thank you very much for your comment.

All the metadata have been provided by Scopus /Elsevier in their last update sent to SCImago, including the Coverage's period data. The SJR for 2020 has been released on 17 May 2021. We suggest you consult the Scopus database directly to see the current index status as SJR is a static image of Scopus, which is changing every day.

Best Regards, SCImago Team

Dear Sir/Madam, thank you very much for your comment, unfortunately we cannot help you with your request. We suggest you to consult the Scopus database directly. Keep in mind that the SJR is a static image (the update is made one time per year) of a database (Scopus) which is changing every day.

Best Regards, SCImago Team 
D Dr. Shalender Kumar, MD (FM) 3 years ago

Sir, I want to submit my manuscript for publication in your journal. So sir on which mail id I can do it sir. Kindly guide me sir. Thanks and regards.

reply

(6)

Elena Corera 3 years ago

SClmago Team

Dear Dr Shalender,

thank you very much for your comment, unfortunately we cannot help you with your

request. We suggest you check author's instructions in journal website. You can find that

information in SJR website https://www.scimagoj.com

Best Regards,

SClmago Team

\section{Leave a comment \\ Name \\ Email \\ (will not be published)}

The users of Scimago Journal \& Country Rank have the possiblity to dialogue through comments linked to a specific journal. The purpose is to have a forum in which general doubts about the processes of publication in the journal, experiences and other issues derived from the publication of papers are resolved. For topics on particular articles, maintain the dialogue through the usual channels with your editor.

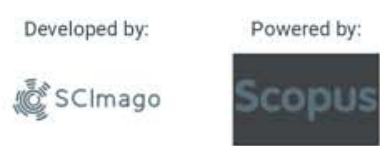

Follow us on @ScimagoJR

Scimago Lab, Copyright 2007-2020. Data Source: Scopus 


\section{Source details}

\section{Indian Journal of Forensic Medicine and Toxicology}

Scopus coverage years: from 2008 to 2021

(coverage discontinued in Scopus)

Publisher: Institute of Medico-Legal Publications

ISSN: 0973-9122 E-ISSN: 0973-9130

Subject area: Social Sciences: Law Medicine: Pathology and Forensic Medicine

Pharmacology, Toxicology and Pharmaceutics: Toxicology Environmental Science: Health, Toxicology and Mutagenesis
CiteScore 2020

0.1

SJR 2020

0.115

SNIP 2020

0.243 (i)

(i)

(i)

Source type: Journal
View all documents $>$
Set document alert
$\square$ Save to source list

CiteScore CiteScore rank \& trend Scopus content coverage

i Improved CiteScore methodology

CiteScore 2020 counts the citations received in 2017-2020 to articles, reviews, conference papers, book chapters and data papers published in 2017-2020, and divides this by the number of publications published in 2017-2020. Learn more >

\section{CiteScore 2020 \\ $0.1=\frac{387 \text { Citations } 2017-2020}{3,509 \text { Documents } 2017-2020}$}

Calculated on 05 May, 2021

\section{CiteScore rank 2020 (i)}

\begin{tabular}{lll} 
Category & Rank Percentile & \\
\hline Social Sciences & & \\
$\begin{array}{l}\text { L Law } \\
\text { Medicine }\end{array}$ & 1lth \\
$\begin{array}{l}\text { Lathology and } \\
\text { Forensic Medicine }\end{array}$ & \#183/191 & \\
& & \\
Pharmacology, & & \\
Toxicology and & & 3rd \\
\hline
\end{tabular}

View CiteScore methodology $>$ CiteScore FAQ $>$ Add CiteScore to your site $\mathbb{O}$ 

About Scopus
Русский язык
Privacy matters
ELSEVIER Terms and conditions $\pi \quad$ Privacy policy $\pi$
Copyright (C) Elsevier B.V ז. All rights reserved. Scopus ${ }^{\circledR}$ is a registered trademark of Elsevier B.V.
We use cookies to help provide and enhance our service and tailor content. By continuing, you agree to the use
of cookies. 


\section{Indian Journal of Forensic Medicine \& Toxicology}

\section{Current Archives About -}

Home / Editorial Team

\section{Editorial Team}

Editor in Chief

Prof S K Dhattarwal

Forensic Medicine, PGIMS, Rohtak, Haryana

E-mail: editor.jifmt@gmail.com

\section{Editor}

Dr. T. Nataraja Moorthy

Forensic Science Faculty of Health \& Life Sciences, Management \& Science University,Malaysia

\section{EDITORIAL ADVISORY BOARD}

1. Prof Sudhir K Gupta, Head, FMT. AIIMS, New Delhi , India

2. Prof Mete Gulmen, Cukurova University, TURKEY

3. Prof. Leandro Duarte De Carvalho, Minas Gerais, Belo Horizante, BRAzIL

4. Dr. Valery Gunas, National Pirogov Memorial Medical University,Vinnytsya, UKRAINE

5. Dr. Rahul Pathak Forensic Science, Dept of Life Sciences ,Anglia Ruskin University, Cambridge, UNITED KINGDOM

6. Prof Emilo Nuzzalese, University of Turin , Italy

7. Dr Noha A. Magdy Elrafie, Forensic Toxicology, Ain Shams University, Cairo, EGYPT

8. Dr Rituja Sharma, Associate Prof, Law, Banasthali Vidyapeeth Jaipur

9. Dr Shankar Bakkanwar (Associote Professor) Forensic Medicine, Kasturba Medical College, Manipal, Karnataka

10. Dr K. Ravikumar , Raksha Shakti University, Ahmedabad, Gujrat.

11. Dr C. Behera (Addll. Prof) Dept of FMT, AIIMS, New Delhi

12. Dr. Kanak Lata Verma, Deputy Director, Toxicology,RFSL, Chanakyapuri New Delhi

13. Dr. Asha Srivastava (Senior Scientific Officer) Forensic Psychology, Central Forensic Science Laboratory, CBI, Delhi

14. Dr. Raghvendra Kumar Vidua, (Associate Prof), FMT, AIIMS Bhopal

15. Dr. Vaibhav Saran (Asst.Prof.) School of Forensic Science, Sam Higginbottom Institute of Agriculture Technology \& Sciences,Allahabad

16. Ms Aparna R. Asst. Prof. Forensic Serology \& Biology, Jain University, Bengaluru

17. Dr. Deepali Jain, Asst Prof, Forensic Science, BB Ambedkar University, Lucknow

18. Prof. NK Aggrawal Forensic Medicine, UCMS, Delhi

19. Prof. Manoj Kumar Mohanty, Forensic Medicine, AIIMS, Bhuvneshwar, Odissha

20. Prof. Amar Jyoti Patowary, Forensic Medicine, NEIGRIHMS, Shillong, Meghalaya

21. Prof S. Venkata Raghava, Forensic Medicine, Banglore Medical College, Bengaluru

22. Prof. Shalini Gupta Oral Pathology and Microbiology, Faculty of Dental Sciences, King George Medical University. Lucknow

23. Prof. Virender Kumar Chhoker Forensic Medicine, Santosh Medical College, Ghaziabad, UP

24. Prof. Dayanand G Gannur, Forensic Medicine, Shri BM Patil Medical College, Hospital \& Research centre, Bijapur, Karnataka

25. Prof Praveen Arora, Forensic Medicine, SAIMS, Indore, MP

26. Prof Barkha Gupta, Saraswathi Institute of Medical Sciences Hapur, Uttar Pradesh India

27. Prof M Prashant Apollo Medical College Hyderabad

28. Prof Dimple Patel , Anatomay, AMC MET Medical College, Ahmedabad, Gujarat

29. Dr Mohammed Nader Shalaby, Associate Professor of Biological Sciences and Sports Health Department, Faculty of Physical Education, Suez Canal University, Egypt 


\section{Vol. 15 No. 1 (2021): Indian Journal of Forensic Medicine \& Toxicology}

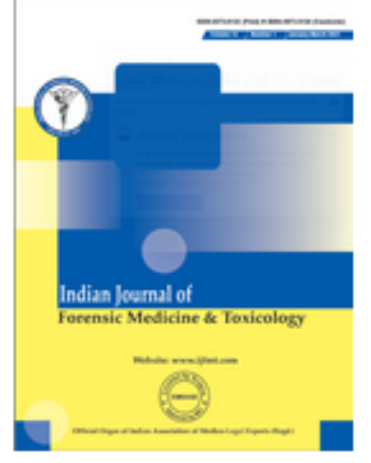

DOI: https://doi.org/10.37506/ijfmt.v15i1

Published: $2021-01-08$

\section{Articles}

Socio-Demographic Profile of Fatal Poisoning in a Tertiary Care Teaching Hospital of Coimbatore District-A Retrospective Study

Angayarkanni S1, Jeyasingh T2

요 PDF

Impact of Pilates Training versus Progressive Muscle Relaxation Technique on Quality of Life in Menopausal Women- A Comparative Study

Anjali Bais1, Pratik Phansopkar2

D PDF

Comparison of Muscle Length in Dominant Versus NonDominant Lower Extremity in Young Asymptomatic Individuals- A Research Protocol

Anushree Pawar1 , Pratik Phansopkar2, KiranKumar3

圆 PDF

Isoniazid Mono Resistance: Changing Trends in Drug Resistant Pulmonary Tuberculosis. - A Case Series of 3 Patients

Arti D. Shah1 , Anchal Jain2, Apoorva3, Kusum V. Shah4, Yash Rana5, Saket kumar6

圆 PDF

Study on Effectiveness of Chakramarda (Cassia tora) Ghrit and Go-Ghrit in the Management of Parikartika (Fissure in Ano)

Alok Kumar Diwedi1,Alok Kumar Diwedi1, Kiran Khandare2, Pooja Shrivastav3 Kiran Khandare2 , Pooja Shrivastav3

国 PDF

Percutaneous Subclavian Artery Covered Stent Placement Following Inadvertent Subclavian Arterial Cannulation Cinosh Mathew1 , R Calton2 
Complex Post Traumatic Stress Disorder (CPTSD) for University Students Natik Fahal Al-Kubaisy1, Uday Khalid Abdul Jabbar Al Qaisy2

\section{Revealing Potency of Bioactive Compounds as Inhibitor of Dengue Virus (DENV) NS2B/N53 Protease from Sweet} Potato Ipomoea batatas L.) Leaves:

Viol Dhea Kharisma1,2, Rasyadan Taufiq Probojati1 , Ahmad Affan Ali Murtadlo1 , Arif Nur Muhammad Ansori3, Yulanda $1627-1632$ Antonius4, Muhammad Badrut Tamam1,5

$$
\text { 国 PDF }
$$

The Role of EMMPRIN in Perirenal Fat Invasion Clear Cell Renal Cell Carcinoma

Vira Yasmina Ramadhani1, 2,3, Anny Setijo Rahaju4,5,6, Nila Kurniasari4,5,6

D PDF

Measuring the Health Impact of Drinking Water Sources in El-Fashir, Sudan

Waed Alahmad1 , Ahmed Abu-Rayyan 2, Najm Eldinn Elsser Elhassan 3,4, Mohammed Ismail Humaida 3,5

D PDF

Incidence of Toxoplasma Gondii and Relationship with Some Inflammatory Factors in Babylon Province Widad Hashim Yahya Almuhana1 , Ahmed Khudhair Al-hamairy2

圆 PDF

Phylogenetic Analysis of TTV (TorqueTeno Virus) in Iraqi Woman Suffering of Failure Kidney Disease YasameenHasan Ali1 , Tariq M Quasim2, DBEL Wahab RAlshaikly3

国 PDF

Comparison of Different Diagnostic Techniques for the Identification of Pulmonary Tuberculosis and Using Serum Tnf-? Levels as a Biomarker for Evaluating the Severity of Tuberculosis

Yaser Jasem1 , Al-khatony2, Halah Abdulkhaliq Awadh Alhadethy3, Mahmood Abduljabar Altobjy4

圆 PDF

Effect of Resveratrol in Expression of Caspase-7 and Retinal Ganglion Cells in a Rat Model With Traumatic Optic Neuropathy

Yunita1,2 Budu3 , Andi Muhammad Ichsan4, Habibah S Muhiddin4,

圆 PDF

The Effect of Ascorbic Acid and Selenium intake on serum Cortisol in rats Under Restraint Stress Zahraa Abdel Al-Jawad1 , Ali A. Al-Fahham2

Gene Expression and Serum IL- 23 in Asthmatic Iraqi Children Zahraa Tahsen Abdulkareem1 , Basima Q. Hasan AL-Saadi2 